\title{
Wobec kapitalistycznej (pseudo)wolności. Teatralne manifesty na postjugosłowiańskich scenach**
}

\begin{abstract}
Against capitalist (pseudo)freedom. Theatrical manifestos on post-Yugoslav stages. The turn of the millennia was full of events fundamental to negotiating and reinterpreting freedom. The citizens of the collapsing federal Yugoslavia, and then the seven new states that were forming, experienced this in a special way. Post-Yugoslav authors of theatrical manifestos, such as Maja Pelević and Olga Dimitrijević from Serbia, Borut Šeparović from Croatia, András Urbán and Zlatko Paković active in the supralocal area, show a special flair for unmasking. They warn that modern ways of exercising freedom leave much to be desired, since they are limited to the consumption of goods and, consequently, to escaping responsibility. In their performances, they are critical of capitalism in its dehumanising, alienating form, which is only an illusion of freedom. These artists, however, do not offer ready-made solutions - their projects are a starting point for further debate on devising the future of the country and region, on attitudes and relationships (including interpersonal), on (re)constructing identity and on the continuous creation of new ranges of possibilities and effects. They use artistic freedom to speak openly about the boundaries of freedom.
\end{abstract}

Keywords: theatre, post-Yugoslav region, freedom, capitalism, responsibility

Kategoria wolności jest intensywnie eksploatowana nie tylko w myśli filozoficznej, lecz także w sztuce i występuje w niej w wielu kontekstach. Teatr, jako za-

* Adres do korespondencji: Wydział Humanistyczny, Instytut Literaturoznawstawa / Instytut Nauk o Kulturze, ul. Sztabowa 96/12, 53-310 Wrocław. E-mail: abrasowicz.gabriela@gmail.com.

** Praca powstała w wyniku realizacji projektu badawczego nr 2017/24/C/HS2/00436, finansowanego ze środków Narodowego Centrum Nauki.

Miscellanea Posttotalitariana Wratislaviensia 8, 2020

(C) for this edition by CNS 
angażowany dokument społecznych przemian, zwierciadło politycznych poglądów i przekonań, a także medium o szczególnej mocy responsywności i reaktywności, konsekwentnie włącza w tok artystycznej artykulacji kwestię wolności wewnętrznej, politycznej, ekonomicznej oraz wolności słowa. Zagadnienia te są też punktami centralnymi wielu spektakli powstających w regionie postjugosłowiańskim.

Oczywiście temat wolności podejmowany był przez twórców teatralnych już wcześniej, przed upadkiem federacji, ale byli oni wówczas dość zachowawczy w swych działaniach. W obawie przed sankcjami artyści stosowali kamuflaż historyczny lub ucieczkę w czystą fantazję, sięgali zarówno po idiom satyryczny, jak i patetyczny, aby odnaleźć język, który pomógłby im bezpiecznie wyrazić odczuwalne zagrożenia dla wolności. Eskalacja etnicznych i narodowych napięć ${ }^{1}$, stopniowe rozbicie Jugosławii na siedem państw i ciągle zmieniająca się rzeczywistość socjopolityczna wygnerowały natomiast wiele projektów scenicznych, które są interwencjami artystycznymi we wspólne doświadczenia zmysłowe. Kolektywnym priorytetem dramatopisarzy i reżyserów organizującego się w latach dziewięćdziesiątych nurtu było czerpanie inspiracji bezpośrednio z życia, zachowanie atmosfery codzienności oraz dystrybucja antyiluzjonistycznych, a nawet antyteatralnych treści ${ }^{2}$. Później nieobca była im także estetyka brutalizmu i teatru postdramatycznego. Po rozpadzie Jugosławii można było się spodziewać przemian polityk kulturalnych, tak istotnie przecież wpływających na kształt i charakter społeczeństwa. Deklarowana otwartość i transparentność w podejściu do kultury (podobnie do innych państw demokratycznych) nie oznaczała jednak skutecznego zminimalizowania liczby przypadków ograniczania autonomii instytucji kultury i swobody artystów, lecz sprowadzona została do uruchomienia nowych mechanizmów (auto)podporządkowania.

Aktualnie wiele państwowych teatrów z długą (jugosłowiańską) tradycją, uwarunkowanych oficjalną i skostniałą polityką repertuarową charakteryzuje ostrożność i raczej dystansowanie się od podejmowania bieżących kwestii społecznych ${ }^{3}$, dlatego scena postjugosłowiańska potrzebuje wyrazistych i radykalnych przedsięwzięć, które zapełniłyby tę swoistą lukę. Twórcy, którzy starają się za wszelką cenę chronić swoje prawo do swobodnego wyrażania poglądów, nawet jeśli niekoniecznie są one podzielane przez większość społeczeństwa czy też konkretne środowiska, zyskują miano lokalnych (a czasem ponadregionalnych) prowokatorów lub skandalistów,

${ }^{1}$ Krwawe wydarzenia ostatniej dekady minionego stulecia na tych terenach to przede wszystkim wojna w Chorwacji w 1991 roku, wojna w Bośni i Hercegowinie w latach 1992-1995, wojna w Kosowie w latach 1998-1999.

2 M. Lazin, „Nova drama - nova gluma?”, [w:] Govor drame. Govor glume. Zbornik radova sa simpozijuma „Dramski tekst danas u Bosni i Hercegovini, Hrvatskoj i Srbiji i Crnoj Gori, red. S. Anđelković, B. Senker, Zagreb 2007, s. 115.

3 Taka inercja była symptomatyczna dla wielu teatrów działających w regionie na początku lat dziewięćdziesiątych XX wieku. Por. M. Đorđević, „Sztuka i polityka w Serbii (1989-1995)”, przeł. M. Ecler, [w:] Bałkany performatywne. Rytuał - dramat - sztuka w przestrzeni publicznej, red. M. Sztandara, G. Injac, W. Kuligowski, Opole 2013, s. 31. 
wśród których prym wiodą Zlatko Paković, Oliver Frljić, Jeton Neziraj czy Nenad Todorović ${ }^{4}$ W wielu przypadkach na mocy postanowień, które mogą niejawnie wywierać presję lub w inny sposób wpływać na decyzje programowe instytucji, ich praca i proces jej upubliczniania zostają zablokowane. Efekty restrykcji dają się zarejestrować zwłaszcza w Serbii, gdzie „po demokratycznych przemianach obecny jest tak zwany postprzejściowy model polityki kulturalnej”" , a tamtejsze życie teatralne obfituje w przykłady cenzury zawieszającej, autocenzury prewencyjnej oraz autocenzury prewencyjnej dla wybranych odbiorców ${ }^{6}$. Autorzy, świadomi dominacji władzy (różnego szczebla) wobec świata artystycznego ${ }^{7}$, boją się dotkliwej kulturowej likwidacji, dlatego są w swych posunięciach bardziej powściągliwi, ale nie brakuje też takich twórców, którzy obawiają się pułapek wolności i niesprawiedliwości z niej płynących. Inny tryb korzystania ze sztuki sprawił bowiem, że „artysta [...] przestał być traktowany jako zakontraktowany interpretator oraz ilustrator idei wspólnych, a stał się twórcą prywatnych komentarzy krytycznych, których nikt nie zamawiał"8, przez co czuje się zagubiony i woli wycofywać się z rewolucyjnych inicjatyw.

Na uwagę zasługują zatem odważne, odpowiedzialne projekty-manifesty, dzięki którym artyści włączają się w dyskusję na temat swobód i odpowiadają na sygnały (samo)ograniczenia wolności (w tym twórczej), a także oferują nowy sposób jej postrzegania i interpretowania. Pomysłodawcy, autorzy i realizatorzy tych przedsięwzięć jako prowolnościowy przedstawiają porządek policentryczny społeczeństwa, w którym równowagę społeczną osiąga się dzięki humanizmowi, dialogowi i interakcji, ponieważ „wolność (czy też jej zaprzeczenie) pojawia się dopiero w relacjach

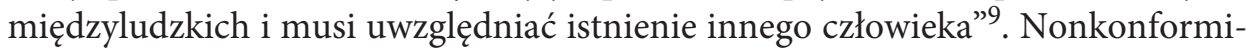
styczni twórcy przełamują jednocześnie strach przed pełniejszym doświadczaniem wolności, ale też przed krytyką antywolnościowych postaw i czynników (takich jak kapitalizm) oraz przed ukazywaniem opcji zmian paradygmatu rozwoju społecznego.

Interesujący mnie w niniejszym artyklule artyści podkreślają, że wolność wymaga ciągłego monitorowania sytuacji i aktywizmu, ponieważ zakres ludzkich możliwości nieustannie się zmienia, a kolejne sytuacje przynoszą nowe perspektywy

${ }^{4}$ Skrajne emocje wywołały między innymi przedsięwzięcia: Ubiti Zorana Đinđića; Vox Dei Građanska neposlušnost, Srebrenica. Kad mi ubijeni ustanemo, Enciklopedija živih Zlatka Pakovicia; Zoran Đinđić, Kukavičluk, Turbofolk, Aleksandra Zec Olivera Frljicia; Bordel Ballkan Jetona Neziraja (w reżyserii Andrása Urbána); LIFT — „Slobodan SHOW”Nenada Todorovicia.

${ }_{5}$ M. Stefanović, „Freedom of expression in contemporary theatre - the right to offend”, Etnoantropološki problemi 2017, nr 12, s. 622 .

${ }^{6}$ Ibidem, s. 623.

7 D. Przastek, Polityki kulturalne a wolność wypowiedzi artystycznej w Polsce w latach 1989-2015, Warszawa 2017, s. 10.

8 M.A. Potocka, „Wolność w sztuce”, MOCAK Forum 2013, nr 2, https://www.mocak.pl/wolnosc-w-sztuce-maria-anna-potocka (dostęp: 11.10.2020).

9 T. Gadacz, „Wolność i odpowiedzialność czyli o "posiadaniu wolności« i »byciu wolnym «", Dialog 1999, nr 9, http://p-ntzp.com/files/09gadacz-p.pdf (dostęp: 11.10.2020). 
i nowe ograniczenia ${ }^{10}$. Przystaje to do ujęcia dynamicznego ${ }^{11}$, w którym wolność jest kreowana, a jej zakres jest zmienny. Poza tym stanowisko twórców projektów artystycznych wskazuje na konieczność sprzężenia z kategorią wolności nieodzownego elementu odpowiedzialności, rozumianej jako stała świadomość determinizmu wyrażającego się w tym, że nie ma zdarzeń bez konsekwencji ${ }^{12}$.

Rozprężenie oraz próby zniesienia znanych ograniczeń mogą skutkować jednak redukcją zarówno wolności pozytywnej, jak i negatywnej ${ }^{13}$ (przynajmniej niektórych grup lub osób), a to może z kolei wywierać wpływ nie tylko na dziedziny ekonomii czy polityki, ale też mieć pewne konsekwencje moralne ${ }^{14}$. Jak zaznaczył w swoim dziele Erich Fromm, uniezależnienie się od podmiotu uciskającego stanowi ważny krok w kierunku osiągnięcia prawdziwie dojrzałej i odpowiedzialnej wolności, jednak może też prowadzić do jeszcze większego ujarzmienia, niebezpiecznego, bo przyjętego przez człowieka dobrowolnie ${ }^{15}$. Stwierdzenie to jest warte szczególnej uwagi w odniesieniu do uwzględnionej tu strefy geokulturowej. Jugosławia funkcjonowała prawie pięćdziesiąt lat jako państwo wielonarodowe według zasady równości oraz „Braterstwa i Jedności”. Wypracowana marka liberalnego socjalizmu ${ }^{16}$ stwarzała pozory wolności i łatwego zaspokajania podstawowych potrzeb. Nadmierny nacisk na zbiorową odpowiedzialność zaowocował jednak typową utratą indywidualności i całkowitym podporządkowaniem Josipowi Brozowi Ticie. Śmierć przywódcy (w 1980 roku) spowodowała kryzys na wszystkich poziomach — zarówno politycznym, społeczno-ekonomicznym, jak i psychologicznym ${ }^{17}$. W okresie demontażu federacji oraz powstawania pęknięć w ponadnarodowej tożsamości, a tym samym wyodrębniania się nowych państw. Wolność była odkrywana na nowo, jak gdyby zmieniła swój rejestr. Utożsamiana odtąd z niepodległością, towarzyszyła też takim kategoriom społecznym jak demokracja, patriotyzm i prawa człowieka.

10 P. Traczyk, „Wolność dynamiczna: przyczynek do rozważań nad ideą wolności pozytywnej”, Annales Universitatis Mariae Curie-Skłodowska 34, 2009, s. 120.

11 P. Traczyk wyjaśnia podział na ujęcie statyczne i dynamiczne wolności oraz zasadność (bądź jej brak) użycia pojęcia wolności „pozytywnej” („wolności do”) i „negatywnej” („wolności od”). Por. ibidem.

12 Ibidem, s. 121.

${ }^{13} \mathrm{Na}$ uwagę zasługuje porównanie ujęcia wolności pozytywnej i negatywnej przez Ericha Fromma i Isaiaha Berlina. Por. A. Wątróbski, „Kategoria »wolności od « i »wolności do« w interpretacji wolności religijnej", Łódzkie Studia Teologiczne 11-12, 2002-2003, s. 345-354.

14 A. Stoiński, „Ryzyko wolności pozytywnej”, Diametros 2016, nr 49, s. 121.

15 J. Urbanek, „Filozofia E. Fromma na podstawie »Ucieczki od wolności«”, Medycyna Nowożytna 13, 2006, nr 1-2, s. 160.

16 Należy podkreślić, że władze Jugosławii wprowadziły w opozycji do Moskwy koncepcję programową tak zwanej trzeciej drogi do socjalizmu (między państwowym komunizmem a gospodarką wolnorynkową), realizując politykę niezaangażowania. W 1948 roku Komunistyczną Partię Jugosławii wykluczono z Kominformu, a wieloetniczna federacja nie powróciła do grupy krajów podporządkowanych ZSRR.

17 D. Radosavljević, „The alchemy of power and freedom - a contextualisation of Slobodan Šnajder's Hrvatski Faust (The Croatian Faust)", Contemporary Theatre Review 2009, nr 19 (4), s. 431.

Miscellanea Posttotalitariana Wratislaviensia 8, 2020

(C) for this edition by CNS 
Oznaczała także niezależność osobistą, prawo do działania, wypowiadania się (co obejmowało również swobodę wypowiedzi artystycznej), wyznania i woli.

Transformacja postjugosłowiańska oznaczała zmianę systemową (przekładającą się z założenia na zmianę mentalnościową), która implikuje działania zmierzające do stabilizacji ekonomicznej i wolności gospodarczej ${ }^{18}$. W krajach wyodrębniających się z dawnej Jugosławii dostrzec można było mniej lub bardziej nasilone starania, które miały na celu zniwelowanie takiej nierównowagi. Opisując przekształcenia postkomunistyczne, Jan Winiecki zaznacza, że w środowisku cywilizacji zachodniej próbę zmiany systemu ekonomicznego można podjąć tylko po skutecznej zmianie systemu politycznego. Co ciekawe, kierunek zmian w krajach postkomunistycznych był odmienny, ponieważ „następował od wzrostu wolności ekonomicznych poprzez wolności obywatelskie (wolność wyznania religijnego, wolność zgromadzeń, wolność słowa itd.) do wolności politycznych"19.

Specyficzne procesy rozpadu i rekonstrukcji Jugosławii (określane terminem „fragstruction” 20 ) są kolejnym dowodem na to, że między polityką, ekonomią a wolnością istnieje skomplikowana więź. Amerykański ekonomista Milton Friedman w swojej książce Kapitalizm i wolność ${ }^{21}$ podkreślał, że wolność dochodzi do głosu tylko w niektórych kombinacjach konkretnych ustaleń o charakterze gospodarczym i politycznym. Friedman wskazał na coraz częstszą w środowisku intelektualistów negację kluczowego znaczenia ekonomicznego aspektu wolności. Odnotował nawet, tak zbieżne z krytyką uprawianą przez postjugosłowiańskich artystów, okazywanie pogardy wobec wszystkiego, co związane jest z materialną sferą życia oraz przywiązywanie zdecydowanie większej wagi do dążeń mających na celu znalezienie wyższych wartości. Obrońca wolnego rynku uznawał bezpośrednie znaczenie wolności ekonomicznej za co najmniej porównywalne z jej znaczeniem pośrednim (traktując ją jako środek do osiągania wolności politycznej). Odwołując się do wydarzeń historycznych, wskazywał, że kapitalizm jest warunkiem koniecznym, ale nie wystarczającym, do zaistnienia wolności politycznej. Jak ta idea zmaterializowała się tuż po rozpadzie Jugosławii?

Obywatele niezależnej Słowenii, Chorwacji, Bośni i Hercegowiny, Macedonii, Serbii, a potem jeszcze Czarnogóry (od 2006 roku) i Kosowa (od 2008 roku $^{22}$ ) stanęli w obliczu nowych wyzwań. Te zmagania o wolność i z wolnością oraz dostrzegalny

18 J. Winiecki, Transformacja postkomunistyczna. Studium przypadku zmian instytucjonalnych, Warszawa 2012, s. 9.

19 Ibidem, s. 10.

20 Specyfikę rozpadu sprzężonego z rekonstrukcją oddaje neologizm „fragstruction” (fragmentation and reconstruction) ukuty przez Sabrinę P. Ramet i Petera Wagnera; za: D. Mikucka-Wójtowicz, „Jak rodzi się demokracja? Typy transformacji”, [w:] E. Bujwid-Kurek, D. Mikucka-Wójtowicz, Transformacja ustroju politycznego wybranych państw Europy Środkowej i Południowo-Wschodniej, Kraków 2015, s. 35.

21 M. Friedman, Kapitalizm i wolność, przeł. B. Sałbut, Gliwice 2018.

22 Władze Kosowa ogłosiły jednostronnie własną niepodległość od Serbii, czego władze Serbii nie akceptują. 
przez twórców teatralnych destrukcyjny wpływ kapitalizmu na kształtowanie autonomii człowieka, potencjał rozwojowy jednostki i prawo do samostanowienia ${ }^{23}$

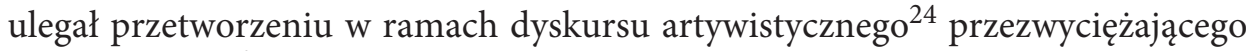
„traumę apatii” ${ }^{25}$. W następującym przeglądzie porządkującym zaprezentuję realizacje sceniczne powstałe w Serbii, Czarnogórze, Bośni i Hercegowinie oraz Chorwacji, których wspólnym mianownikiem jest projekcja niepożądanych efektów ekspansji kapitalizmu. Zestawię tu formy i strategie reprezentacji, jakie przyjęli wybitni artyści z regionu postjugosłowiańskiego, aby zareagować na ten problem i współtworzyć doświadczenia nie tylko estetyczne, lecz także etyczno-polityczne.

\section{Wolność kontrolowana}

Znane w serbskim świecie teatralnym Maja Pelević i Olga Dimitrijević w poszukiwaniu odpowiedzi na nurtujące je pytania dotyczące wolności udały się do najbardziej odizolowanego obecnie kraju, w którym panuje represyjny, totalitarny system, pogardzany przez demokratyczny świat. Projekt Sloboda je najskuplja kapitalistička reč ([Wolność to najdroższe kapitalistyczne słowo $]^{26}, 2016$, Bitef teatar, Belgrad) powstał mianowicie na podstawie materiałów zdobytych podczas wyprawy badawczej autorek do Korei Północnej. Artystki wychodzą z założenia, że właśnie ten kraj jako ostatnia pozostałość zimnej wojny może powiedzieć odbiorcom wiele o zachodnim świecie, w którym rzekomo zaspokajane są wszelkie indywidualne potrzeby i pragnienia.

Dramatopisarki, a w tym wypadku reżyserki i wykonawczynie, przedstawiają $\mathrm{w}$ formie interakcyjnego show swoje impresje z podglądania życia w socjalistycznym raju (a może piekle?). (Auto)ironicznie roztrząsają złożone problemy społeczeństw neoliberalnych i ukazują globalny kryzys społeczny, niezliczone napięcia i chaotyczne sprzeczności w dzisiejszym świecie, w którym panuje permanentny

23 T. Szkudlarek, „Wolność ponowoczesna i pedagogika dekonstrukcji”, [w:] Dylematy wolności, red. M. Reut, Wrocław 2001, s. 225.

${ }^{24}$ Art + activism - zaangażowana społecznie twórczość wykorzystywana w walce z niesprawiedliwością i uciskiem. Por. Y. Goris, S. Hollander, Activism, Artivism and Beyond. Inspiring initiatives of civic power, Partos 2017, https://www.partos.nl/fileadmin/files/Documents/Activism_Artivism_and_ Beyond.pdf (dostęp: 12.10.2020).

25 N. Govedić, „Trauma apatije: dvije dramatičarske postjugoslavenske Nigdine (Ivana Sajko i Biljana Srbljanović)", [w:] Dramski tekst danas u Bosni i Hercegovini, Hrvatskoj, Srbiji i Crnoj Gori (Međunarodni simpozijum univerzitetskih predavača, teatrologa i pozorišnih kritičara), red. S. Anđelković, Novi Sad 2004, s. 156.

26 Odwołanie do tytułu cyklu wykładów Matii Bećkovicia, które odbyły się w Australii, Europie i Jugosławii w 1989 roku podczas obchodów sześćsetnej rocznicy bitwy na Kosowym Polu, a także książki autorstwa tego pisarza i członka Serbskiej Akademii Nauk Kosovo - Najskuplja srpska reč [Kosowo - najdroższe serbskie słowo], wydanej w 1989 roku przez „Głos Cerkwi”. Warto przypomnieć, że od 1989 roku pogrążoną w kryzysie ekonomicznym Jugosławię zaczęła ogarniać fala dążeń narodowowyzwoleńczych. 
konsumpcyjny niepokój. Artystki zastanawiają się nad względnością i determinacją wolności przez kontekst społeczno-kulturowy. Skłaniają odbiorców do refleksji nad relacjami wolności i, odpowiednio, widzialnego kultu jednostki oraz niewidzialnego kultu kapitału.

Wybór terenu badań nie był oczywiście przypadkowy. Przeważyła tu chęć wzmocnienia przekazu poprzez kontrastowe zestawienie kodów kulturowych i politycznych oraz uzmysłowienia odbiorcom, że żyjemy w czasach narastającego globalnego nadzoru, a jednocześnie manipulacji społeczeństwem, któremu narzucany jest ideał wolności powiązanej z konsumpcjonizmem. Krytyka Zachodu, kapitalizmu, wolnej gospodarki rynkowej, rzekomego zniesienia barier i wszystkiego, co jest całkowitym przeciwieństwem rzeczywistości Korei Północnej, splata się z próbą usprawiedliwienia totalitaryzmu w jego najbardziej brutalnym wariancie jako zła mniejszego niż zachodnia kapitalistyczna „wolność”, z której autorki (urodzone jeszcze w okresie trwania Jugosławii) wydają się nieco niezadowolone.

Podsumowaniem spektaklu jest projekcja krótkiej eksplikacji. Twórczynie pojawiają się w mundurach na ekranie filmowym i podważają swoje dotychczasowe słowa oraz dystansują się od przedstawionych spostrzeżeń. Zarzucają Oldze i Mai występującym przed publicznością brak odwagi, by przyznać się do zachwytu nad systemem bezpłatnej opieki zdrowotnej i edukacji, zapewnionej pracy, mieszkań socjalnych, odgórnej organizacji wszelkich aktywności. One także zostały uwiedzione obietnicą „łatwej” wolności z kolorowego supermarketu, osiąganej fikcyjnymi środkami.

\section{Marks wiecznie żywy}

Współczesne wymiary i wyznaczniki wolności analizuje również urodzony w Wojwodinie reżyser węgierskiego pochodzenia András Urbán. Punktem wyjścia jego autorskiego spektaklu Kapital ([Kapitał], 2016, Zetski dom - Kraljevsko pozorište, Cetinje) są podstawowe idee sztandarowego dzieła Karola Marksa, być może nawet bardziej aktualnego teraz, w czasach panowania bezwzględnego i zdziczałego neoliberalnego kapitalizmu niż w momencie tworzenia Krytyki ekonomii politycznej ${ }^{27}$. Dzisiejsze znaczenia relacji między pracą a kapitałem — pracownikami najemnymi i kapitalistami, obraz ciągłego odtwarzania układu nierówności oraz bezdusznego dyktatu konsumeryzmu są sugestywnie konkretyzowane w kontekście czarnogórskim.

W obecnej sytuacji, gdy społeczeństwo Czarnogóry zatruwają bezlitośni egoistyczni złotouści pseudopatrioci, wszelkiego rodzaju liderzy, skupieni na szybkim zysku, którzy podżegają ludzi do nietolerancji wobec wyimaginowanych „wrogów”

27 M. Mrđenović, Kapital: Uzećemo vam sve!, http://peripetija.me/critic.130.critic.html\# (dostęp: 12.10.2020). 
i wciągają ich w otchłań, Kapitał staje się przede wszystkim symbolem indywidualnego uwolnienia i wzięcia odpowiedzialności za swoje życie. Kwestie te wybrzmiewają nie tylko w płaszczyźnie tematycznej, lecz także przez prowokacyjne akty teatralne. Na samym początku przedstawienia publiczność zostaje uroczyście wezwana przez aktorów do należytego oddania szacunku ojczyźnie poprzez wykonanie hymnu Czarnogóry (jest to nawiązanie do niedawnych tragikomicznych praktyk wprowadzenia anachronicznych kar za niewstawanie w trakcie hymnu). Ten wstęp odzwierciedla stopień „wyprania mózgów”, „zatrucia ideą zbiorowej tożsamości”, tresurę wprowadzaną przez elity polityczne, które bezwstydnie podsycają konflikt na tle etnicznym i religijnym, aby odwrócić uwagę zwykłych zjadaczy chleba od własnych nadużyć.

Następujące po tym epizody i songi wyrażają opór wobec przesadnie eksploatującego systemu, który zabija empatię i alienuje człowieka, czyniąc z niego towar. András Urbán wraz z dramaturżką Vedraną Božinović nakreślili kontinuum między czasem pojawienia się idei marksistowskich a współczesnością oraz zaakcentowali potrzebę stałej czujności, wyrazu dezaprobaty, buntu i nieposłuszeństwa wobec demagogii.

Ten rodzaj politycznego muzyczno-recytacyjnego performansu wyrywa widza ze strefy komfortu i bierności. Podczas ekskursji w przestrzeń krytyki społecznej nie oszczędzono nikogo: ani lewicy, ani prawicy, ani kapitalizmu, ani socjalizmu, ani czarnogórskich elit politycznych, ani nacjonalistów, ani liberałów, ani nowobogackich, ani nawet wyzyskiwanych biednych, którzy swoją biernością zasłużyli na zniewolenie. Punktem kulminacyjnym jest orgiastyczna wręcz scena kompulsywnego pochłaniania fastfoodowych produktów spożywczych. Wykonawcy, którzy wychodzą z roli zmanipulowanych „schizofrenicznych zombie”, przemawiają ostatecznie $\mathrm{w}$ swoim imieniu. Ich zwierzenia dotyczące złożonego procesu artystycznego oraz prywatnych problemów intensyfikują wykrzykiwane ze sceny hasła: „Kapitalizm to bombonierka, którą zanosisz lekarzowi przed operacją! Kapitalizm to nerka, której nie otrzymasz do transplantacji!"28.

\section{Obnażona Wolna Europa}

András Urbán wyreżyserował także postdramatyczny performans What is Europe? Ratni obred ([Czym jest Europa? Rytuał wojenny], 2016, Scena MESS - ART HUB, Sarajewo). Podstawę tekstualną tego sarajewskiego przedsięwzięcia tworzy zbiór esejów pochodzącego z Wojwodiny László Végela Ispaštanjeili priče iz donjih predela/Bünhödés: úti szövegek [Pokuta albo opowieści z dolnych pejzażów], w których autor odnosi się krytycznie do jugosłowiańskiego dziedzictwa, ale też do strategii rozwoju Unii Europejskiej. Cykl tekstów napisanych w tonie konfesyjnym

28 V. Božinović, A. Urbán, Kapital (Skrypt), przeł. G. Abrasowicz. 
z punktu widzenia emigranta ujawnia walkę obywateli krajów byłej Jugosławii o status Europejczyka, o wysoki standard życia i, po latach ograniczeń, wolność osobistą.

Teksty Végela i ich nadbudowa w postaci segmentów bazujących na improwizacjach aktorskich zostały przedstawione $\mathrm{w}$ formie przypominającej koncert rockowy o Europie jako fabrykowanej iluzji. Ze Starym Kontynentem (a konkretniej — jego zachodnimi terenami) kojarzone są kulturowe, historyczne i humanistyczne wartości, prawodawstwo, respektowanie zasad, szacunek dla ludzkiego życia i dbanie o jego jakość. Droga ku Europie, czyli ku wyobrażeniu lepszego jutra, oznacza jednak rezygnację z historii, ojczyzny, tożsamości. Wykonawcy przestrzegają, że wszyscy opuszczający post-Jugosławię mają najpierw status wygnańców, a potem, gdy przybywają do Europy Zachodniej - niewolników. Europejczycy gorszego sortu wkraczają na nowe obszary geo-kulturowo-polityczne, ale nie zyskują praw przysługujących tubylcom. Oczekuje się od nich asymilacji i integracji, a odstępstwo od normy uznawane jest za porażkę.

"Jesteśmy wolni” — oświadczają z ironią aktorzy, ale wiedzą, że wolność jest kolejną przywdziewaną maską (tuż po rozpadzie Jugosławii nosili bałkańskie maski, które były tylko egzotyczną atrakcją), a transmisja gospodarczo-politycznych obyczajów zachodnioeuropejskich imperiów jest formą kolonialnego ucisku. Skandują dalej: „Niech żyje wolność, która nic nie znaczy. Stękamy pod ciężarem tej wolności. Jęczymy, ale tanecznym, lekkim krokiem serwujemy espresso prawdziwym Europejczykom"29. Barbarzyńców z peryferii ogarnął marazm, nie walczą ani przeciwko konsekwencjom komunistycznej dyktatury, ani o wolność. Zagłuszyli swoje wyższe potrzeby, a ich interpersonalne uczucia zostają podporządkowane regułom gospodarki rynkowej ${ }^{30}$. Kolekcjonowanie dóbr i uczestnictwo w kulturze konsumenckiej nie zapewni im jednak antidotum na późnonowoczesne lęki ${ }^{31}$.

\section{Zniewolone młode umysły}

Rezultat współpracy chorwackiej grupy Montažstroj, Zagrzebskiego Teatru Młodych i Akademii Sztuki Dramatycznej w Zagrzebiu — spektakl Mladež bez Boga ([Młodzież bez Boga], 2019, Montažstroj - ZeKaeM — ADU, Zagrzeb) wyrósł z fascynacji dwoma tekstami: powieścią Ödöna von Horvátha pod tym samym tytułem (Jugend ohne Gott, 1938) i książką Heroes: Mass Murder and Suicide [Bohaterowie. Masowe zabójstwo i samobójstwo, 2015] Franco „Bifo” Berardiego. Te główne linie - opisy narastającego faszyzmu, aktywizacji młodych w kontrze do pasywności i konformizmu dorosłych oraz sceny przygotowań do wojny zaczerpnięte z utworu

${ }^{29}$ L. Végel, „Ispaštanje”, [w:] What is Europe? Ratni obred, program spektaklu, przeł. G. Abrasowicz, s. 10.

30 T. Szlendak, Supermarketyzacja. Religia i obyczaje seksualne młodzieży w kulturze konsumpcyjnej, Wrocław 2004, s. 136.

${ }^{31}$ Ibidem, s. 172. 
austriackiego pisarza oraz rozważania włoskiego marksisty nad zjawiskiem „school-shootingu" splatają się z materiałami dokumentalnymi, manifestami, zapisami zeznań Andersa Breivika, treściami zaczerpniętymi z portali internetowych, nagraniami z kamerek, screenshotami z gry Doom, zdjęciami z aplikacji Snapchat i Face Swap. To ciekawe, jak sprawnie udało się autorowi i reżyserowi tego multimedialnego spektaklu - Borutowi Šeparoviciowi - przetransponować elementy odległej rzeczywistości na rodzimy grunt i dotknąć newralgicznych punktów chorwackiej codzienności. Odkrywa on królestwo nihilizmu, w którym rozbrzmiewa teza Bifo, że ludzie uwięzieni w codziennie odtwarzanym spektaklu neoliberalnego kapitalizmu mogą się wyswobodzić tylko dzięki śmierci. Berardi analizuje pamiętniki morderców i wyjaśnia, że nie chodzi tu wyłącznie o skłonności socjopatyczne, ale o to, jak młodzi ludzie, w swoich poszukiwaniach autorytetów, wchłaniają niczym gąbka otaczający ich antyhumanizm.

W spektaklu Šeparovicia młodzież przygotowuje się do wojny w kontekście rewolucji STEM (Science, Technology, Engineering, Mathematics) i traci kontakt z tradycyjnymi wartościami społecznymi, takimi jak solidarność oraz tolerancja. Bohaterowie recytują wyuczone hasła, wierząc między innymi w to, że zmiana obrazu demograficznego i kapitalizm są podłożem kryzysów i konfliktów. Ci młodzi, biali gniewni kompensują swój brak sprawczości (nieumiejętność planowania i konstruowania przyszłości), uciekając w świat brutalnych gier komputerowych i przeczesując zasoby Dark Webu. Niemal każda scena eksponuje problem wyobcowania i podatności młodych na treści serwowane w mediach, które są potężną bronią w nowej walce ideologicznej, a także skutecznie zawężają ramy wolności i wypaczają jej znaczenie.

\section{Podsumowanie, wsparte jeszcze jednym przykładem}

Artyści ukazują obecny, nowoczesny schemat kulturowy ze spuścizną poprzedniego systemu jako antypodę wolności. Swoje manifesty ilustrują obrazami niemożności rezygnacji z przywiązania do złudzenia bezpieczeństwa oraz przykładami bezrefleksyjnego podążania za dobrami, kompensowania faktycznych niedostatków i zachłyśnięcia się surogatami. Uzmysławiają oni odbiorcom, że rozmycie granic wywołuje stany zagubienia w relatywizmie i prowadzi do unikania konfrontacji oraz do wytwarzania w sobie mechanizmów ucieczki od normalnego rozwoju psychospołecznego w bardziej komfortowe wymiary rzeczywistości (zgodnie z diagnozą Fromma, który wyróżnił „nowe, wtórne więzy” jako sposoby ucieczki od wolności $^{32}$ ). Dlatego też w swoich projektach scenicznych twórcy nie pomijają fenomenu odpowiedzialności.

W omówione tu przekazy wplatane są nierzadko jugonostalgiczne wątki, ale tylko po to, aby unaocznić nowe (a czasem powracające, reaktywowane) formy znie-

32 E. Fromm, Ucieczka od wolności, przeł. O. Ziemielska, A. Ziemielski, Warszawa 2015, s. 102. 
wolenia i skłonić publiczność do refleksji nad sposobami „odciążenia” i „uczłowieczenia” wolności, która umożliwi wtedy kształtowanie jakości życia ze szczególnym uwzględnieniem relacji międzyludzkich (tak osłabianych przez kapitalizm).

Ukierunkowana krytyka i nawoływanie do odwrotu od kapitalizmu w propozycjach twórców aktywnych w regionie postjugosłowiańskim jest zjawiskiem o coraz większym natężeniu ${ }^{33}$. Potwierdza to trafność spostrzeżenia Zlatka Pakovicia, że jest to „kluczowy temat współczesnego europejskiego teatru, który wciąż poszukuje jasnego i zwięzłego przedstawienia" ${ }^{34}$. Serbski reżyser również prezentuje zagrożenie płynące z faktu, że kapitalistyczne transakcje wkroczyły na wszystkie poziomy ludzkiego życia, czego dobitnym przykładem jest jego autorski spektakl Kapitalizam, geometrijskim redom izložen ([Kapitalizm: w porządku geometrycznym dowiedziony], 2016, Kosztolányi Dezső Színház, Subotica). Paković wraz z węgierskim zespołem szczególnie obrazowo demaskuje miraże konsumpcyjnego „wolnego świata”, a jednocześnie studzi euforię wywołaną namiastką stabilizacji i stara się konstruktywną krytyką wskazać możliwości inicjowania zmian. Publiczność poznaje historię migrantów, którzy dotarli do Suboticy (miasta na granicy serbsko-węgierskiej) i, chcąc utrzymać się przy życiu, decydują się na otwarcie zakładu przetwórstwa szczurzego mięsa. Przedsiębiorstwo nie tylko utrzymuje się na rynku, ale rozrasta się, bo głodnych w okolicy nie brakuje, wystarczy tylko przełamać opory i zmienić nawyki żywieniowe. Tę zmianę konwencji w celu napędzania odhumanizowanej machiny reżyser prezentuje jako szczyt perwersji kapitalistycznej pseudoetyki.

Stopień, w jakim kapitalizm wrósł w naszą rzeczywistość, oddają w pełni słowa jednego z songów, które przecinają tkankę tej sztuki:
KAPITALIZM TO KOŁYSANKA NA USTACH MATKI
Kapitalizm to nie tylko system społeczno-polityczny.
Kapitalizm to nie tylko system etyczny.
Kapitalizm to także sposób odczuwania.
Kapitalizm to także sposób zmysłowości, postrzegania i reagowania.
Kapitalizm to sposób śnienia i marzenia.
Kapitalizm to także sposób walki z kapitałem, zyskiem i burżuazyjnymi bzdurami!
Kapitalizm jest wężem w trzewiach proletariatu!

${ }^{33}$ O niesłabnącym zainteresowaniu tym tematem i potrzebie rewizji wyobrażeń dotyczących wolności świadczy tryb opracowań scenicznych autorstwa Mileny Bogavac (Smrt fašizmu! O Ribarima i Slobodi - Śmierć faszyzmowi! O Ribarach i Slobodzie), Kokana Mladenovicia (Jami distrikt - Dystrykt Jami, we współautorstwie z M. Bogavac), Bojana Đorđeva (Budućnost pročitana u betonu i kamenu — Przyszłość wyczytana w betonie i kamieniu), Olgi Dimitrijević (Radio Šabac), wiele projektów Zlatka Pakovicia, Jetona Neziraja oraz Olivera Frljicia, a także wybrane edycje festiwali i przeglądów poświęcone zagadnieniu wolności, z których warto tu wymienić INFANT w 2016 roku (odbywający się w Nowym Sadzie Międzynarodowy Festiwal Alternatywnego i Nowego Teatru). Jego program określał prowokacyjny slogan Po ile wolność? Strategia selekcjonerki Jeleny Kajgo, która musiała zmagać się z ograniczeniami budżetu, polegała na wyborze reprezentatywnych spektakli skłaniających publiczność do zastanowienia się nad statusem wolności, głównie nad jej obiektualizacją i utowarowieniem.

34 A. Isakov, „Surova etika kapitalizma”, Politika, 21.12.2016, http://www.politika.rs/sr/clanak/ 370525/Kultura/Surova-etika-kapitalizma (dostęp: 11.10.2020). 
Kapitalizm to kołysanka na ustach matki! zabawy!

Kapitalizm to forma estetycznej przyjemności i sposób na rozrywkę, która jest obietnicą szalonej

Kapitalizm nie jest tak nudny jak doktryna materializmu dialektycznego.

Kapitalizm to uwodziciel, który obiecuje cyrk krwi, łez i potu,

Dla ciebie, tylko dla ciebie, bo na to zasługujesz, tylko ty,

Tylko ty, tylko ty, tylko ty... ${ }^{35}$

Ponadto w swoich filozoficznie zabarwionych wypowiedziach Paković alarmuje, że kapitalizm osiągnął szczyt przebiegłości, budując metody oporu przeciwko samemu sobie, aby mieć je pod kontrolą. Powstało wprawdzie wiele spektakli, które programowo kwestionują ten konkretny system gospodarki rynkowej i polemizują z friedmanowskim neoliberalizmem, ale sposób ich realizacji, tak jak relacje między publicznością i twórcami, opierają się właśnie na kapitalistycznych regułach ${ }^{36}$. Pozostaje zatem obserwować, czy autorom kolejnych inicjatyw i eksperymentów scenicznych uda się uniknąć tej pułapki.

\section{Bibliografia}

Đorđević , Marko. 2013. „Sztuka i polityka w Serbii (1989-1995)”. Przeł. Martyna Ecler. W: Bałkany performatywne. Rytuat - dramat - sztuka w przestrzeni publicznej, red. Magdalena Sztandara, Goran Injac, Waldemar Kuligowski, 23-34. Wydawnictwo Uniwersytetu Opolskiego: Opole.

Friedman, Milton. 2018. Kapitalizm i wolność. Przeł. Bartosz Sałbut. Gliwice: Helion.

Fromm, Erich. 2015. Ucieczka od wolności. Przeł. Olga Ziemilska, Andrzej Ziemilski. Warszawa: Wydawnictwo Czytelnik.

Gadacz, Tadeusz. 1999. „Wolność i odpowiedzialność czyli o posiadaniu wolności i byciu wolnym”, Dialog 9.

Goris, Yannicke, Saskia Hollander. 2017. Activism, artivism and beyond. Inspiring initiatives of civic power, https://www.partos.nl/fileadmin/files/Documents/Activism_Artivism_and_Beyond.pdf (dostęp: 12.10.2020).

Govedić, Nataša. 2004. Trauma apatije: dvije dramatičarske postjugoslavenske Nigdine (Ivana Sajko i Biljana Srbljanović). W: Dramski tekst danas u Bosni i Hercegovini, Hrvatskoj, Srbiji i Crnoj Gori (Međunarodni simpozijum univerzitetskih predavača, teatrologa i pozorišnih kritičara). Red. Sava Anđelković, 149-162. Novi Sad: Sterijino pozorje.

Isakov, Ana. 2016. „Surova etika kapitalizma”, Politika, 21 grudnia, http://www.politika.rs/sr/clanak/370525/Kultura/Surova-etika-kapitalizma (dostęp: 11.10.2020).

Lazin, Miloš. 2007. „Nova drama - nova gluma?”. W: Govor drame. Govor glume. Zbornik radova sa simpozijuma "Dramski tekst danas u Bosni i Hercegovini, Hrvatskoj i Srbiji i Crnoj Gori”. Red. Sava Anđelković, Boris Senker, 112-123. Zagreb: Disput.

Mikucka-Wójtowicz, Dominika. 2015. „Jak rodzi się demokracja? Typy transformacji”. W: Ewa Bujwid-Kurek, Dominika Mikucka-Wójtowicz, Transformacja ustroju politycznego wybranych państw Europy Środkowej i Południowo-Wschodniej, 29-36. Kraków: Libron.

Mrđenović, Maja. 2018. Kapital: Uzećemo vam sve!, http://peripetija.me/critic.130.critic.html\# (dostęp: 12.10.2020).

35 Z. Paković, Kapitalizam, geometrijskim redom izložen (Skrypt), przeł. G. Abrasowicz.

36 A. Isakov, op. cit.

Miscellanea Posttotalitariana Wratislaviensia 8, 2020

(C) for this edition by CNS 
Paković, Zlatko. Kapitalizam, geometrijskim redom izložen (Skrypt). Przeł. Gabriela Abrasowicz.

Potocka, Maria A. 2013. „Wolność w sztuce”, MOCAK Forum 2, https://www.mocak.pl/wolnosc-w -sztuce-maria-anna-potocka (dostęp: 11.10.2020).

Przastek, Daniel. 2017. Polityki kulturalne a wolność wypowiedzi artystycznej w Polsce w latach 19892015. Warszawa: Dom Wydawniczy Elipsa.

Radosavljević, Duška. 2009. „The alchemy of power and freedom - a contextualisation of Slobodan Šnajder's Hrvatski Faust (The Croatian Faust)", Contemporary Theatre Review 19, nr 4: 428-447.

Stefanović, Milica. 2017. „Freedom of expression in contemporary theatre - the right to offend”, Etnoantropološki problemi 12: 621-640.

Stoiński, Andrzej. 2016. „Ryzyko wolności pozytywnej”, Diametros 49: 121-138.

Szkudlarek, Tomasz. 2001. „Wolność ponowoczesna i pedagogika dekonstrukcji”. W: Dylematy wolności, red. Maria Reut, 219-236. Wrocław: Oficyna Wydawnicza Politechniki Wrocławskiej.

Szlendak, Tomasz. 2004. Supermarketyzacja. Religia i obyczaje seksualne młodzieży w kulturze konsumpcyjnej. Wrocław: Wydawnictwo Uniwersytetu Wrocławskiego.

Traczyk, Przemysław. 2009. „Wolność dynamiczna: przyczynek do rozważań nad ideą wolności pozytywnej", Annales Universitatis Mariae Curie-Skłodowska 34: 109-122.

Urbanek, Joanna. 2006. „Filozofia E. Fromma na podstawie »Ucieczki od wolności«”, Medycyna Nowożytna 13, nr 1-2: 137-170.

Wątróbski, Adam. 2002-2003. „Kategoria »wolności od « i »wolności do« w interpretacji wolności religijnej”, Łódzkie Studia Teologiczne 11-12: 345-354.

Winiecki, Jan. 2012. Transformacja postkomunistyczna. Studium przypadku zmian instytucjonalnych. Warszawa: Wydawnictwo C.H. Beck.

Przyjęto do druku/Accepted for publication: 15.09 .2020

Miscellanea Posttotalitariana Wratislaviensia 8, 2020

(C) for this edition by CNS 